\title{
CHARACTERISTICS OF TECHNOLOGY TRANSFER IN ROMANIAN ORGANIZATIONS
}

\author{
Simona Cătălina ȘTEFAN ${ }^{a}$, Cezar-Petre SIMION ${ }^{b}$, Ștefan Cătălin POPA ${ }^{c}$ \\ a,b,cBucharest University of Economic Studies, Romania
}

DOI: $10.24818 / \mathrm{IMC} / 2020 / 02.16$

\begin{abstract}
In this research, in order to know the opinion of the subjects involved in the technology transfer processes, a survey was conducted based on a technology transfer questionnaire. The majority of the respondents to the questionnaire are represented by researchers from research institutes or by teachers from university education involved in research-development, technological development and innovation activities. In the case of universities and national research and development institutes, the research centers / sections / laboratories constitute, in the vast majority of cases, the organizational entities involved in the technology transfer processes. The situation is radically different in the case of private research institutes where the technology transfer centers and technology brokers are the most important entities involved in technology transfer processes.
\end{abstract}

KEYWORDS: technology transfer, organizations, Romania

\section{INTRODUCTION}

The development of new products / services or the renewal of existing ones, as a result of technical and technological progress is an important vector of economic growth and social welfare, having in the same time positive effects at the microeconomic level (of companies), by increasing sales, market share of profit (Cicea, Marinescu \& Moroianu, 2015). If large companies and multinational organizations have to choose between the results of their own research departments and those produced by universities or research institutes, small and medium-sized companies do not usually have a structural representation of the research-development function since they would not afford the associated costs (Burdus \& Popa, 2018). That is why they either take over the results of research abandoned by large companies in developed countries or those generated by national researchdeveloped systems. The exception is usually innovative start-ups or spin-offs, the establishment of which is even a way of productive concretization of some results of research and development activities. Therefore, technology transfer is one of the ways in which organizations in the productive sector manage to meet their internal needs for renewal / resizing / improvement of the portfolio of products, services, works or activities. One of the most frequently used sources of technology transfer is the assimilation in the productive sector of the results obtained through applied research, technological development and innovation activities.

In Romania, the technological transfer between the research and development sector and the beneficiaries of this transfer has always been a topic of discussion both in terms of its characteristics and the efficiency of the process as a whole (Nicolescu L. \& Nicolescu C, 2012; Sandu, 2014). If the multinational organizations present on the Romanian market satisfy their needs in the field of new technologies through internal transfers, the Romanian organizations, most often the small and medium ones are forced to resort (in the absence of their own research - development activities) to the results offered by the national research-development system.

\footnotetext{
* Corresponding author. E-mail address: simona.stefan@man.ase.ro
} 
Although there have been a number of previous studies that have addressed the issue of technology transfer (Caramihai, et al., 2017; Vlădut, 2017), their results have not been based on consulting both entities involved in technology transfer processes: organizations that generate results that are subject to technology transfer and organizations that assimilate these results in their own production processes.

The purpose of the research is to have a representation of the characteristics of the technology transfer process from the perspective of human resources employed in the two main categories involved in technology transfer processes: technology providers and their beneficiaries. From this perspective, the research carried out involves obtaining relevant answers to the following questions:

- Who are the organizational entities involved in the technology transfer processes?

- Are there differences between technology transfer organizations and beneficiaries in terms of organizational entities involved in technology transfer processes?

- What methods of technology transfer are currently used and what methods will be used in the future by Romanian organizations involved in technology transfer processes?

- Is there a link between the technology transfer modalities currently used and those expected to be used in the future?

The answers to these questions constitute a more complete characterization of the particularities of the technological transfer in the Romanian organizations in relation to the previous researches, as they were formulated on the basis of the opinions of the subjects directly involved in these processes.

\section{LITERATURE REVIEW}

The concern for the issue of technology transfer and its characteristics is not new. De Moortel and Crispeels (2018) considered that universities are, both in developed and emerging economies, are key players in technology transfer processes and thus contributing to the development of their own regions and countries. Fox et al. (2013) describe the mechanisms and effects of a technology transfer project between a research institute in the US and one in Romania emphasizing the idea that the first recipient of a technology transfer process from a developed to an emerging country can be a research-development organization that owns or develops the technology within its own production or micro-production capacities. The most important idea of the study by Fox et al. is that one of the most important mechanisms of technology transfer is the projects jointly developed by research and development institutions. The existence of research centers in emerging countries that have concerns similar to those in developed countries is one of the safest ways to transfer technology. Nicolescu O. and Nicolescu C. (2017) considered that innovation intensifies and diversifies with a great impact on the sustainability of organizations.

Garcia - Vega and Chirrivela (2020) conducted a large-scale study that included 10,000 Spanish companies benefiting from technology transfer over a period of eight years, concluding that the technology transfer of research results from universities to the private sector has encouraged innovation of the companies.

Nevolin and Kozyrev (2014) proposed a specific module to facilitate technology transfer by showing that web platforms align the expectations of new technology licensees with those of their potential beneficiaries. In developing their mode, they therefore started from the premise of an asymmetry between the needs and expectations of the actors involved in the technology transfer processes. This view on technology transfer processes is also shared by Caramihai et al. (2017) which define them as the process of dividing the results of research-development between two parties, one of which has the results and the other has the ability to assimilate them in manufacturing and to market them. 
Caramihai et al. considers that the two parties involved in technology transfer processes have different interests and views on technology transfer processes and have a number of proposals on improving technology transfer processes in Romania: simplifying the legal framework on technology transfer; the support of entities with a facilitating role of technology transfer; improving the activities of capitalizing on research results within public domain organizations. Sandu (2014) considers that the Romanian research-development market is marked by a lack of concordance between the results produced by organizations in the field of research-development and the demand of potential customers. These previous studies reveal the existence of previously identified problems regarding technology transfer and highlight the importance of studying and knowing the characteristics of technology transfer processes in Romanian organizations.

\section{RESEARCH METHODOLOGY}

Given the need to know the main characteristics of technology transfer processes, the research was conducted based on a questionnaire-based survey (Ștefan et al., 2020) involving respondents from both research and development organizations (universities, institutes, research centers) and organizations that operates in the productive sector. Those rare characteristics of the studied population determined their selection trough snowball sampling (a non-probabilistic sampling technique).

The main topics addressed by this paper are those on organizational entities involved in technology transfer (both in general and on different types of organizations), the importance given to technology transfer modalities, the assessment of satisfaction with the way it is carried out technology transfer process, technology transfer methods used in the future. Based on the processing of the questionnaire results, descriptive statistics and analysis of the correlations between the degree of use of a technology transfer method and the satisfaction given to a technology transfer method were performed.

The analysis of the correlations between the degree of use of a technology transfer modality and the satisfaction given to a technology transfer modality was performed to reveal the link between the measure of using a technology transfer modality at present and the preference of the surveyed subjects on its future use. their opinion on the organizations' preference for a certain way of technology transfer). This relationship between the satisfaction felt now and the future use has been studied for the main ways of technology transfer: the subcontracted development of new products / services; license agreements; consulting activity.

\section{RESEARCH RESULTS}

\subsection{Sample structure}

In order to know the opinion of the subjects involved in the technology transfer processes, a survey was conducted based on a technology transfer questionnaire. The questionnaire-based survey was involved 103 respondents from organizations involved in technology transfer processes. The majority of the respondents to the questionnaire are represented by researchers from research institutes or by teachers from university education involved in research-development, technological development and innovation activities (figure no. 1). They are followed by engineers specializing in technological development from companies or research institutes. Fewer respondents are those who have the profession of economist or other professions (technical expert, designer). 


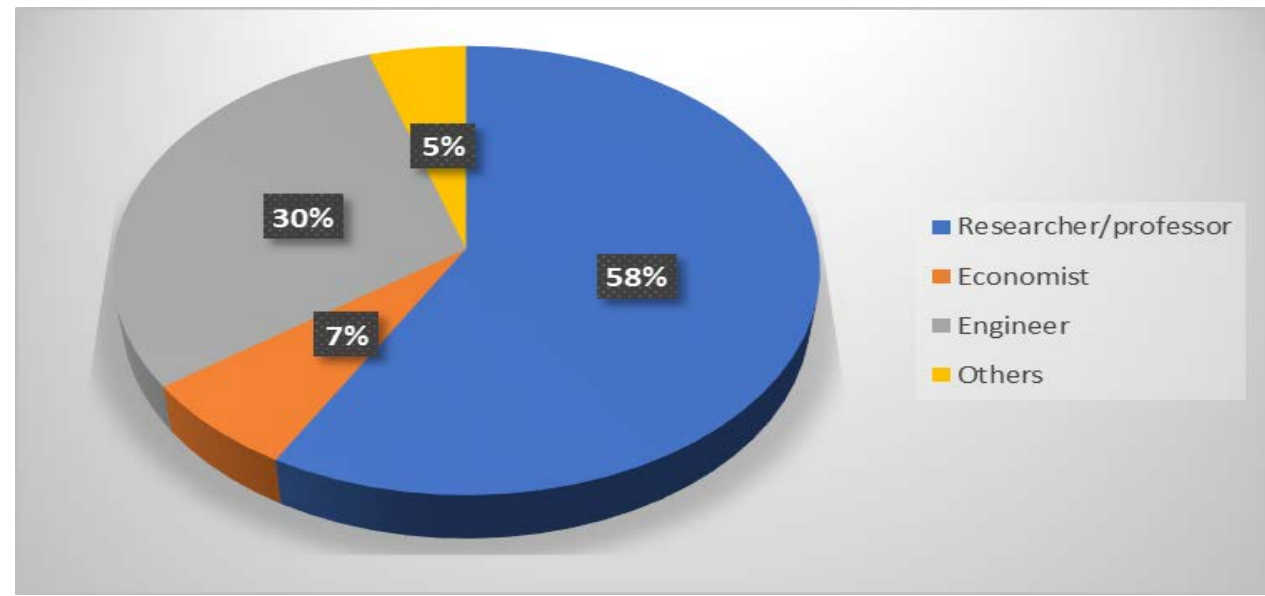

Figure 1. Sample structure according to the position (profession) of the respondents Source: own calculations with SPSS Statistics 27.0 (IBM Corp., 2020)

The structure of the sample according to the professional experience of the respondents is presented in figure 2.

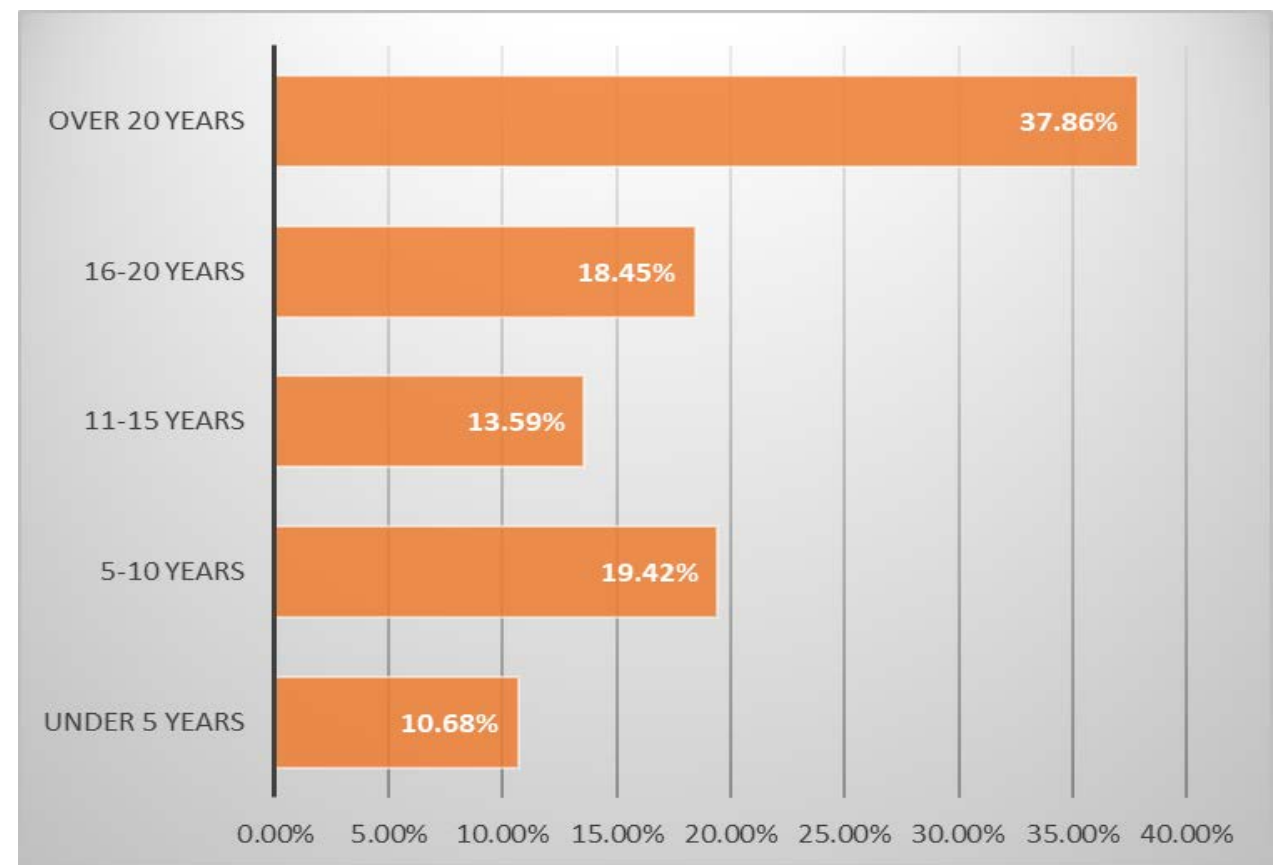

Figure 2. Sample structure depending on the professional experience of the respondents

Source: own calculations with SPSS Statistics 27.0 (IBM Corp., 2020)

As can be seen from the previous figure, most respondents have either a very high level of professional experience (over one third of respondents have over 20 years of professional experience) or a high level of experience (almost a fifth of respondents are between 16 and 20 years). Except for the $10 \%$ who are in the beginning of their professional life and the rest of the respondents have a relevant professional experience (between 6 and 15 years) to reveal a series of defining elements of the technology transfer processes. The professional experience of the respondents to the questionnaire-based survey is the one that gives a high degree of relevance to their assessments on some aspects of the technology transfer processes between the research development and innovation system in Romania and the rest of the economic sectors. 
The structure of the sample according to the professional experience of the respondents largely reflects the share of research and development staff in Romanian organizations, in which predominate researchers and auxiliary staff with great experience and less those in the early stages of career.

\subsection{Descriptive statistics}

The perception of the respondents of the questionnaire regarding the organizational entities involved in the technology transfer is presented in Table 1.

Table 1.Organizational entities involved in technology transfer
\begin{tabular}{|l|c|c|}
\hline $\begin{array}{c}\text { Organizational entities involved } \\
\text { in technology transfer }\end{array}$ & Frequency & Percent \\
\hline Research centers / sections / laboratories & 58 & $56.31 \%$ \\
\hline Industry Liaison Office & 3 & $2.91 \%$ \\
\hline Technology transfer center & 8 & $7.77 \%$ \\
\hline Innovation centers & 8 & $7.77 \%$ \\
\hline Technological resource centers & 3 & $2.91 \%$ \\
\hline Business incubators & 5 & $4.85 \%$ \\
\hline Scientific park & 1 & $0.97 \%$ \\
\hline Research park & 1 & $0.97 \%$ \\
\hline Technology brokers & 3 & $2.91 \%$ \\
\hline None & 9 & $8.74 \%$ \\
\hline Another entity & 4 & $3.88 \%$ \\
\hline Total & $\mathbf{1 0 3}$ & $\mathbf{1 0 0 . 0 0 \%}$ \\
\hline
\end{tabular}

Source: own calculations with SPSS Statistics 27.0 (IBM Corp., 2020)

More than half of the respondents appreciated that the research centers / sections / laboratories are organizational entities involved in technology transfer. These are followed in the hierarchy of questionnaire responses by the technology transfer center, innovation centers and business incubators. Less represented in the opinions of the respondents of the questionnaire are: the industry liaison office, technology brokers (or technology brokers), technology resource centers, science park or research park. Almost $9 \%$ of respondents appreciated that within the organizations in which they operate there is no entity involved in technology transfer processes.

Respondents mentioned (depending on the specifics of the activity of their own organizations) and other organizational entities involved in technology transfer processes:

- research department,

- design department,

- Technical Directorate,

- Technical Service.

The analysis of the organizational entities involved in the technology transfer processes depending on the typology of the organizations leads to a large extent, to relatively similar results for most types of organizations in the RDI sphere, according to the data presented in Table 2.

sections / laboratories constitute, in the vast majority of cases, the organizational entities involved in the technology transfer processes. In the case of universities, the research centers are followed by the technology transfer center, the innovation centers and to a lesser extent by the technological resource centers and the science park. Respondents from national institutes have only one other entity highlighted as being involved in technology transfer processes: innovation centers.

The situation is radically different in the case of private research institutes where the technology transfer center and technology brokers (or technology brokers) are the most important entities involved in technology transfer processes. 
Table 2. Organizational entities involved in technology transfer by types of organizations

\begin{tabular}{|l|c|c|c|c|c|}
\hline \multirow{2}{*}{$\begin{array}{c}\text { Organizational } \\
\text { entities involved in } \\
\text { technology } \\
\text { transfer }\end{array}$} & University & $\begin{array}{c}\text { National } \\
\text { Research and } \\
\text { Development } \\
\text { Institute }\end{array}$ & $\begin{array}{c}\text { Type of organization } \\
\text { Research } \\
\text { Institute } \\
\text { (private } \\
\text { property) }\end{array}$ & Company & $\begin{array}{c}\text { Public } \\
\text { institution } \\
\text { (other than in } \\
\text { the field of } \\
\text { RDI) }\end{array}$ \\
\hline \hline $\begin{array}{l}\text { Research centers / } \\
\text { sections / } \\
\text { laboratories }\end{array}$ & $67.86 \%$ & $94.29 \%$ & $18.18 \%$ & $17.39 \%$ & $0.00 \%$ \\
\hline $\begin{array}{l}\text { Industry Liaison } \\
\text { Office }\end{array}$ & $0.00 \%$ & $0.00 \%$ & $9.09 \%$ & $4.35 \%$ & $16.67 \%$ \\
\hline $\begin{array}{l}\text { Technology transfer } \\
\text { center }\end{array}$ & $14.29 \%$ & $0.00 \%$ & $36.36 \%$ & $0.00 \%$ & $0.00 \%$ \\
\hline Innovation centers & $10.71 \%$ & $5.71 \%$ & $0.00 \%$ & $13.04 \%$ & $0.00 \%$ \\
\hline $\begin{array}{l}\text { Technological } \\
\text { resource centers }\end{array}$ & $3.57 \%$ & $0.00 \%$ & $0.00 \%$ & $4.35 \%$ & $16.67 \%$ \\
\hline Business incubators & $0.00 \%$ & $0.00 \%$ & $9.09 \%$ & $17.39 \%$ & $0.00 \%$ \\
\hline Scientific park & $3.57 \%$ & $0.00 \%$ & $0.00 \%$ & $0.00 \%$ & $0.00 \%$ \\
\hline Research park & $0.00 \%$ & $0.00 \%$ & $9.09 \%$ & $0.00 \%$ & $0.00 \%$ \\
\hline Technology brokers & $0.00 \%$ & $0.00 \%$ & $18.18 \%$ & $4.35 \%$ & $0.00 \%$ \\
\hline None & $0.00 \%$ & $0.00 \%$ & $0.00 \%$ & $30.43 \%$ & $33.33 \%$ \\
\hline Another entity & $0.00 \%$ & $0.00 \%$ & $0.00 \%$ & $8.70 \%$ & $33.33 \%$ \\
\hline \multicolumn{1}{|c|}{ Total } & $\mathbf{1 0 0 . 0 0 \%}$ & $\mathbf{1 0 0 . 0 0 \%}$ & $\mathbf{1 0 0 . 0 0 \%}$ & $\mathbf{1 0 0 . 0 0 \%}$ & $\mathbf{1 0 0 . 0 0 \%}$ \\
\hline & Source: $0 \mathrm{wn}$ calculations with SPSS Statistics $27.0(\mathrm{IBM}$ Corp., 2020) \\
\hline
\end{tabular}

In the case of universities and national research and development institutes, the research centers / About a third of respondents in companies and public institutions indicated that there is no organizational entity involved in technology transfer processes in their own organizations. In the case of private companies but also of privately owned research institutes, business incubators seem to be some of the organizational entities most involved in technology transfer processes.

Data on organizational entities involved in technology transfer by type of organization reveal the following two characteristics:

- the tendency of RDI organizations in the public sector is to use research centers / sections / laboratories as the main organizational entities involved in technology transfer processes:

- RDI organizations in the private sector (research institutes and companies with RDI activities in their portfolio) mainly use other organizational entities in technology transfer processes (specialized centers, brokerage and business incubators).

The organizational entities involved in the technology transfer depending on the position of the organization in this process are presented in the table 3.

For the respondents from the organizational entities that transfer technology, the most important organizational entities involved in technology transfer are the research centers / sections / laboratories followed by the technology transfer centers, which is normal as they come mostly from research institutes and publicly owned universities. Other organizational entities involved in technology transfer indicated by the same respondents are (to a lesser extent) business incubators, science park or specialized brokerage. The respondents from the entities that assimilate the technology considered to the greatest extent that the organizations in which they operate do not have entities specialized in technology transfer or that these are the research centers / sections / laboratories. To a lesser extent, they considered that innovation centers, business incubators and technology resource centers are used in technology transfer processes. 
Table 3. Organizational entities involved in technology transfer by position in the technology transfer process

Position in the technology transfer process

\begin{tabular}{|l|c|c|c|c|}
\hline \multirow{2}{*}{$\begin{array}{c}\text { Organizational } \\
\text { entities involved in technology } \\
\text { transfer }\end{array}$} & $\begin{array}{c}\text { Entity that } \\
\text { transfers the } \\
\text { technology }\end{array}$ & $\begin{array}{c}\text { The entity } \\
\text { that } \\
\text { assimilates } \\
\text { the } \\
\text { technology }\end{array}$ & $\begin{array}{c}\text { Position in the technology transfer process } \\
\text { regulating } \\
\text { the } \\
\text { technology } \\
\text { transfer } \\
\text { process }\end{array}$ & None \\
\hline $\begin{array}{l}\text { Research centers / sections / } \\
\text { laboratories }\end{array}$ & $73.53 \%$ & $25.00 \%$ & $0.00 \%$ & $25.00 \%$ \\
\hline Industry Liaison Office & $0.00 \%$ & $3.57 \%$ & $66.67 \%$ & $0.00 \%$ \\
\hline Technology transfer center & $10.29 \%$ & $0.00 \%$ & $0.00 \%$ & $25.00 \%$ \\
\hline Innovation centers & $7.35 \%$ & $10.71 \%$ & $0.00 \%$ & $0.00 \%$ \\
\hline Technological resource centers & $0.00 \%$ & $7.14 \%$ & $0.00 \%$ & $25.00 \%$ \\
\hline Business incubators & $2.94 \%$ & $10.71 \%$ & $0.00 \%$ & $0.00 \%$ \\
\hline Scientific park & $1.47 \%$ & $0.00 \%$ & $0.00 \%$ & $0.00 \%$ \\
\hline Research park & $0.00 \%$ & $3.57 \%$ & $0.00 \%$ & $0.00 \%$ \\
\hline Technology brokers & $2.94 \%$ & $3.57 \%$ & $0.00 \%$ & $0.00 \%$ \\
\hline None & $1.47 \%$ & $28.57 \%$ & $0.00 \%$ & $0.00 \%$ \\
\hline Another entity & $0.00 \%$ & $7.14 \%$ & $33.33 \%$ & $25.00 \%$ \\
\hline \hline & $\mathbf{1 0 0 . 0 0 \%}$ & $\mathbf{1 0 0 . 0 0 \%}$ & $\mathbf{1 0 0 . 0 0 \%}$ & $\mathbf{1 0 0 . 0 0 \%}$ \\
\hline
\end{tabular}

Source: own calculations with SPSS Statistics 27.0 (IBM Corp., 2020)

To the question "To what extent do you attach importance to the following ways of technology transfer in your organization?" the respondents to the questionnaire-based survey indicated the cooperative research programs / projects as the most important way of technology transfer (according to the data presented in table 4). The next way of technology transfer (in order of importance given by the respondents) is the consultancy activity which is either limited to the RDI activity of the specialized organizations, or represents an independent activity without direct link with the RDI activities of the organizations.

Table 4. The importance given to technology transfer modalities

\begin{tabular}{|l|c|c|}
\hline \multicolumn{1}{|c|}{$\begin{array}{c}\text { Technology transfer } \\
\text { modalities }\end{array}$} & Mean & $\begin{array}{c}\text { Standard } \\
\text { deviation }\end{array}$ \\
\hline Cooperative research programs / projects & 4.301 & 1.170 \\
\hline Consulting activity & 3.680 & 1.096 \\
\hline Selling / buying products or services & 3.320 & 1.050 \\
\hline Subcontracted development of new products / services & 3.184 & 1.027 \\
\hline License agreements & 2.592 & 1.133 \\
\hline \multicolumn{2}{|c|}{ Source: own calculations with SPSS Statistics 27.0 (IBM Corp., 2020) }
\end{tabular}

From the analysis of the data presented in table 4 it can be seen that the subcontracted development of new products / services and license agreements are less represented in the respondents' opinions. It reveals that RDI activities do not lead research results to the level of licensing as well as the disinterest of entities that assimilate technology to this method of technology transfer.

To the question "To what extent are you satisfied with the way the technology transfer process takes place in your organization?" the respondents appreciated the consulting activity the most, according to the data in Table 5. 


\begin{tabular}{|c|c|c|c|c|c|c|}
\hline \multirow{2}{*}{$\begin{array}{c}\text { Technology transfer } \\
\text { modalities }\end{array}$} & \multicolumn{3}{|c|}{ Degree of use } & \multicolumn{3}{|c|}{ Degree of satisfaction } \\
\hline & $M$ & $S D$ & Variance & $M$ & SD & Variance \\
\hline \multicolumn{7}{|c|}{ Subcontracted development of new products / services } \\
\hline Product & 2.660 & 1.369 & 1.874 & 2.311 & 1.213 & 1.471 \\
\hline Service & 3.796 & 1.061 & 1.125 & 3.204 & 1.051 & 1.105 \\
\hline Technology & 3.243 & 1.089 & 1.186 & 2.777 & 1.102 & 1.214 \\
\hline \multicolumn{7}{|c|}{ Consulting activity } \\
\hline Analysis & 4.262 & 1.019 & 1.038 & 3.757 & 1.062 & 1.127 \\
\hline Studies & 4.214 & 1.117 & 1.248 & 3.738 & 1.066 & 1.136 \\
\hline Personnel training services & 3.515 & 1.047 & 1.095 & 3.291 & 1.025 & 1.052 \\
\hline \multicolumn{7}{|c|}{ License agreements } \\
\hline Patents & 2.126 & 1.319 & 1.739 & 1.845 & 1.282 & 1.642 \\
\hline Trademarks & 1.990 & 1.248 & 1.559 & 1.767 & 1.139 & 1.298 \\
\hline Models & 2.971 & 1.216 & 1.480 & 2.476 & 1.153 & 1.330 \\
\hline Industrial design & 2.437 & 1.288 & 1.660 & 2.029 & 1.224 & 1.499 \\
\hline Knowhow & 3.563 & 1.063 & 1.131 & 3.068 & 1.157 & 1.338 \\
\hline
\end{tabular}

Note: $\mathrm{M}=$ mean; $\mathrm{SD}=$ standard deviation.

Source: own calculations with SPSS Statistics 27.0 (IBM Corp., 2020)

Within the consulting activity, the most appreciated way of technological transfer was the performance of analyzes followed by studies. The least appreciated method of technology transfer was licensing on a contract basis and within it the lowest satisfaction was that in relation to trademarks and patents. This means that, according to respondents, patents and trademarks, insofar as they exist, are less valued and / or valued in the context of technology transfer.

To the question "What ways of technology transfer do you think will be used in the future by your organization?" the respondents indicated as the main way of technological transfer the realization of research programs / projects in cooperation, followed by the consultancy activity (according to the data in table 6).

Table 6. Technology transfer methods used in the future

\begin{tabular}{|l|c|c|c|}
\hline \multicolumn{1}{|c|}{$\begin{array}{c}\text { Technology transfer methods } \\
\text { used in the future }\end{array}$} & $\boldsymbol{M}$ & $\boldsymbol{S D}$ & Variance \\
\hline Cooperative research programs / projects & 4.359 & 1.083 & 1.174 \\
\hline Consulting activity & 4.000 & 0.970 & 0.941 \\
\hline Selling / buying products or services & 3.495 & 1.065 & 1.135 \\
\hline Subcontracted development of new products / services & 3.282 & 0.974 & 0.949 \\
\hline License agreements & 2.845 & 1.135 & 1.289 \\
\hline
\end{tabular}

Note: $\mathrm{M}=$ mean; $\mathrm{SD}=$ standard deviation.

Source: own calculations with SPSS Statistics 27.0 (IBM Corp., 2020)

According to the respondents, other transfer methods used in the future will be:

- partnership for innovation,

- trainings.

It is noted that respondents, both in the area of the national research and development and innovation system and in the entities that assimilate technology, want to take advantage in the future of the opportunities offered by the innovation partnership as a procedure for awarding public procurement contracts. for services (present as a separate award procedure since 2016). 


\subsection{Analysis of the correlations between the degree of use of a technology transfer method and the satisfaction given to a technology transfer method}

The analysis of the correlations between the degree of use of a technological transfer modality and the satisfaction granted to a technological transfer modality is presented in table 7 .

Table 7. Analysis of the correlations between the degree of use of a technology transfer method and the satisfaction given to a technology transfer method

\begin{tabular}{|c|c|c|c|c|c|c|c|}
\hline \multirow[t]{2}{*}{$\begin{array}{c}\text { Technology transfer } \\
\text { modalities }\end{array}$} & \multicolumn{2}{|c|}{ Degree of use } & \multicolumn{2}{|c|}{$\begin{array}{c}\text { Degree of } \\
\text { satisfaction }\end{array}$} & \multicolumn{3}{|c|}{ Correlations } \\
\hline & $M$ & $S D$ & $M$ & SD & $r$ & $\tau_{\mathbf{b}}$ & $\mathbf{r}_{\mathrm{s}}$ \\
\hline \multicolumn{8}{|c|}{ Subcontracted development of new products / services } \\
\hline Product & 2.660 & 1.369 & 2.311 & 1.213 & $0.678 * * *$ & $0.598 * * *$ & $0.683 * * *$ \\
\hline Service & 3.796 & 1.061 & 3.204 & 1.051 & $0.495 * * *$ & $0.456^{* * *}$ & $0.521 * * *$ \\
\hline Technology & 3.243 & 1.089 & 2.777 & 1.102 & $0.520 * * *$ & $0.457 * * *$ & $0.520 * * *$ \\
\hline \multicolumn{8}{|c|}{ Consulting activity } \\
\hline Analysis & 4.262 & 1.019 & 3.757 & 1.062 & $0.567 * * *$ & $0.514 * * *$ & $0.566^{* * *}$ \\
\hline Studies & 4.214 & 1.117 & 3.738 & 1.066 & $0.607 * * *$ & $0.509 * * *$ & $0.554 * * *$ \\
\hline Personnel training services & 3.515 & 1.047 & 3.291 & 1.025 & $0.444 * * *$ & $0.381 * * *$ & $0.434 * * *$ \\
\hline \multicolumn{8}{|c|}{ License agreements } \\
\hline Patents & 2.126 & 1.319 & 1.845 & $\overline{1.282}$ & $0.847 * * *$ & $0.660 * * *$ & $0.715 * * *$ \\
\hline Trademarks & 1.990 & 1.248 & 1.767 & 1.139 & $0.770 * * *$ & $0.706 * * *$ & $0.759 * * *$ \\
\hline Models & 2.971 & 1.216 & 2.476 & 1.153 & $0.625 * * *$ & $0.577 * * *$ & $0.659 * * *$ \\
\hline Industrial design & 2.437 & 1.288 & 2.029 & 1.224 & $0.750 * * *$ & $0.630 * * *$ & $0.715 * * *$ \\
\hline Knowhow & 3.563 & 1.063 & 3.068 & 1.157 & $0.670 * * *$ & $0.598 * * *$ & $0.678 * * *$ \\
\hline
\end{tabular}

$\mathrm{M}=$ mean; $\mathrm{SD}=$ standard deviation. $\mathrm{r}=$ Pearson correlation coefficient. $\tau_{\mathrm{b}}=$ Kendall correlation coefficient. $r_{g}$

$=$ Spearman correlation coefficient. $* \mathrm{p}<0.05 . * * \mathrm{p}<0.01 . * * * \mathrm{p}<0.001$

Source: own calculations with SPSS Statistics 27.0 (IBM Corp., 2020)

As can be seen from Table 7, there are significant correlations between the degree of use of technology transfer methods and the satisfaction given to these technology transfer methods. In the case of technology transfer modalities that involve the subcontracted development of new products / services, the most significant correlation is between the degree of use and the degree of satisfaction related to the products $\left(\mathrm{r}=0.688, \tau_{\mathrm{b}}=0.598, \mathrm{r}_{\mathrm{s}}=0.683, \mathrm{p}<0.001\right)$.

Regarding the consultancy activity, the most significant correlation between the degree of use and the degree of satisfaction is the one that appears in the case of studies $\left(\mathrm{r}=0.607, \tau_{\mathrm{b}}=0.509, \mathrm{r}_{\mathrm{s}}=\right.$ $0.554, \mathrm{p}<0.001)$ and analyzes $\left(\mathrm{r}=0.567, \tau_{\mathrm{b}}=0.514, \mathrm{r}_{\mathrm{s}}=0.566, \mathrm{p}<0.001\right)$. Studies and analyzes are, moreover, the most used and appreciated ways of technology transfer according to the opinions of the respondents based on the questionnaire.

Less obvious seems the link between the degree of use and the degree of satisfaction with the use of staff training services as they are not perceived as a form of technology transfer but rather as a service associated with this process which most often has the role of complementing it. and to complete it, especially from the perspective of the beneficiaries. As a significant part of the respondents come from national research and development institutes that do not have tertiary education or staff training services as their object, they are less valued in the respondents' opinions. In the case of license agreements, the most significant correlations are those between the degree of use and the degree of satisfaction related to patents $(\mathrm{r}=0,847, \tau \mathrm{b}=0,660, \mathrm{rs}=0,715, \mathrm{p}<0.001)$, trademarks $(\mathrm{r}=0.770, \tau \mathrm{b}=0.706, \mathrm{rs}=0.759, \mathrm{p}<0.001)$ and industrial design $(\mathrm{r}=0.750, \tau \mathrm{b}=$ $0.630, \mathrm{rs}=0.715, \mathrm{p}<0.001)$. The relatively limited use of patents and trademarks in technology transfer processes generates dissatisfaction of the parties involved in the process (authors of patents and their potential users). Between the degree of use and the degree of satisfaction related to the 
know-how and models, there are important links but lower in value than those registered in terms of patents, trademarks and industrial design. However, licensing agreements as a means of technology transfer seem to be the least used by respondents compared to the consulting activity or the subcontracted development of new products / services. This means that the activity of patenting and trademark registration is not followed in the same proportion by their acquisition by entities in the productive sector.

The inclusion of analyzes or studies in the consulting activity is itself problematic from the perspective of respondents' perception because, at least for respondents from research institutes and (partially) universities, it can be assimilated to the research activity itself.

\section{CONCLUSIONS}

The article presents a research based on a questionnaire on the main characteristics of technology transfer processes in Romanian organizations. Researchers from research institutes or universities have the largest share among the respondents to the questionnaire. The most experienced of them also have the highest share among the respondents of the questionnaire. Questionnaire survey respondents indicated cooperative research programs / projects as the most important technology transfer modality currently used. Most of the respondents considered that the research centers / sections / laboratories are the main organizational entities involved in the technology transfer. These are followed in the hierarchy of questionnaire responses by the technology transfer center, innovation centers and business incubators. From this point of view, there was a differentiation between the opinions of the respondents from the public environment (focused on the centers / sections / research laboratories) and those from the private environment (who considered other ways of technology transfer besides the centers / sections / research laboratories). The research revealed through correlation analysis that there are significant correlations between the degree of use of technology transfer methods and the satisfaction given to these technology transfer methods. The respondents are oriented towards the same ways of technology transfer that have given satisfaction in the past and seem to be tempted to use them mainly in the future. One limitation of the research is its focus on the exclusive approach of the relationship between research and development organizations with those in the productive field in technology transfer processes, without taking into account the technology transfer between productive organizations internationally or between research-development organizations internationally, revealed in the research conducted by Fox et al (2013). That is why in future research they will be included in questionnaire-based surveys and topics that take into account the issue of international technology transfer.

\section{Acknowledgment}

This research was conducted with the support received within the research project "Analysis of the current situation of Romanian research and ways to achieve the transfer of new technologies in the productive sector, in the effort to develop the knowledge-based economy".

\section{REFERENCES}

Burduș, E. \& Popa, I. (2018). Fundamentele managementului organizației, București: ProUniversitaria.

Caramihai (Guda), M., Tănase, N. M. \&Purcărea, A. A. (2017). Proposals for Improving Innovation and Technology Transfer Policies in Romania, Procedia Engineering, 181, 984-990. doi: 10.1016/j.proeng.2017.02.497. 
Cicea, C., Marinescu, C., \& Moroianu, N. (2015). Innovation process and business functions'implication in the new product development process. In Proceedings of the $9^{\text {th }}$ International Management Conference, Bucharest, Romania, pp. 227-233.

De Moortel, K. \& Crispeels, T., (2018). International university-university technology transfer: Strategic management framework, Technological Forecasting \& Social Change, 135, 145-155. doi:10.1016/j.techfore.2018.05.002.

Fox, C. B., Huynh, C., O'Hara, M. K. \& Onu, A. (2013). Technology transfer of oil-in-water emulsion adjuvant manufacturing for pandemic influenza vaccine production in Romania, Vaccine, 31(12), 1633-1640. doi:10.1016/j.vaccine.2012.10.048.

García-Vega, M. \& Vicente-Chirivella, O. (2020). Do university technology transfers increase firms' innovation?, European Economic Review, 123, 103388. doi:10.1016/j.euroecorev.2020.103388.

IBM Corp. (2020). IBM SPSS Statistics for Windows, Version 27.0. Armonk, NY: IBM Corp.

Nevolina, I., Kozyrev, A. (2014). Developing CRIS module for technology transfer, Procedia Computer Science, 33, $158-162$.

Nicolescu, O. \& Nicolescu, C. (2017). Recent World Tendencies in the Organisation Environment, Proceedings of the $11^{\text {th }}$ International Management Conference, Bucharest, Romania, pp. 438445.

Nicolescu, L. \& Nicolescu, C. (2012). Innovation in SMEs - Findings from Romania. Economics \& Sociology, 5, 71-85.

Sandu, S. (2014) Market of R\&D results in Romania, Procedia Economics and Finance, 8, 649 657. doi:10.1016/S2212-5671(14)00140-3.

Ștefan, S. C., Simion, C. P, Popa, Ș. C., Albu, C. F. \& Potcovaru, A.M. (2020). Enablers and barriers of technology transfer in Romanian organizations in the context of the knowledgebased economy - a factor analysis, Manuscript submitted for publication.

Vlăduţ, G. (2017). Innovation ecosystem model for commercialization of research results, Proceedings of the International Conference on Business Excellence, Sciendo, 11(1), 10201032 